\title{
Is Early Partnership Formation Instrumental for Fertility in Germany?
}

\author{
Influences of Fertility Orientations on Partnership Transitions
}

\section{Okka Zimmermann}

\begin{abstract}
Using panel data from childless respondents of the German Family Panel (pairfam, $n=3,802$ respondents), this paper investigates whether fertility orientations (biographical orientations with respect to fertility) influence the risk of different partnership transitions among German men and women over the age of 18 (for $n=14,572$ observation periods between two panel waves). Significant influences are found for both gender and partnership transition types, and are generally stronger among men than women and for the transition to a coresidential as opposed to a romantic partnership. Uncertainty about anticipated fertility has a stronger negative impact on transition risks among men than among women.

Results strongly suggest that the early stages of the partnership formation process are instrumental in terms of future fertility in Germany, at least to some degree. This indicates that a more comprehensive conceptualisation and analysis of fertility within the life course paradigm (as suggested by Huinink/Kohli 2014) should consider the impacts of fertility orientations on life course events in other dimensions, especially among men. Viewed more broadly, the results also underline two factors: the role of agency in coordinating life course dimensions in time and space in order to maximise individual welfare; and the importance of considering the impacts that anticipation of future life course events will have, as suggested by different theoretical approaches.
\end{abstract}

Keywords: Fertility · Partnership · Coresidential partnership · Life course • Biographical orientations 


\section{Introduction}

The link between partnership formation and childbearing within individual lives is to some extent unclear. One assumption of life course theory (e.g. Bernardi et al. 2019; Huinink/Feldhaus 2009; Mayer 2019), but also of theories on individualisation (e.g. Beck 1992) as well as differentiation of private life (e.g. Meyer 1992, 2014), is that individuals increasingly have to coordinate requirements and goals across life course domains which have become more independent of one other. Empirical research is therefore required to establish just how strong the link between two different life course dimensions (e.g. partnership and childbearing) is within a specific context or group.

As far as Germany in particular is concerned, a comparatively strong link exists between marriage and childbearing, with childbirth outside marriage having recently risen to about a third in 2019 (Statista 2020). In comparison with other countries, this figure is still low (Eurostat 2018). Furthermore, there is a strong norm prevalent in Germany of two children being the ideal family size (Ruckdeschel et al. 2018; Schröder et al. 2016). The German context is thus specific insofar as the meaning of childbearing is concerned, because this act is tied more strongly to marriage (and thus to the strong institutionalisation of a partnership) than in many other European countries (Nave-Herz 2015; Konietzka/Kreyenfeld 2017; Lappegård et al. 2017). All three of the latter studies also emphasise that marriage is still considered to be the most preferable setting for childbearing in Germany, and that it is indeed often the intention of having children which leads to the intention to marry. However, the strong link between childbearing and marriage in Germany indicates that the link between childbearing and other forms of partnership is less robust.

Today, a romantic non-coresidential partnership in Germany is typically followed first by a coresidential partnership, then by marriage, and finally by childbearing (Konietzka/Zimmermann 2020; Kopp et al. 2010). These forms of partnership therefore often constitute stages within a differentiated process of partnership and family formation. However, given the existence of other forms of non-coresidential and coresidential partnership (e.g. Lois 2012; Hiekel et al. 2014, 2015; Ostner 2001; Cherlin 2004), the link between coresidential and non-coresidential partnerships on the one hand and childbearing on the other hand is not completely clear. Furthermore, a high proportion of men and women remain childless in Germany (around 20 percent, Kreyenfeld/Konietzka 2017, leading, among other things, to low total fertility rates). This suggests that family formation has become just one of the options available for people's individual life courses. Accordingly, Meyer $(1992,2014)$ hypothesises that individuals increasingly choose between different principles in the way they organise their private life (child-centred, partnershipcentred or individualistic). Similarly, Aries (1980) argues that, since the 1960s, raising children is no longer the core aim of couples but is instead merely one method of potential self-realisation and self-fulfilment within couple relationships (see also Zaidi/Morgan 2017). Keddi $(2006,2010)$ emphasises that this is particularly the case among young women, for whom a variety of different role models exist, ranging from the traditional homemaker to a focus on a professional career. Taken 
together, it remains unclear how close the link between early partnership formation and childbearing actually is. As far as Germany in particular is concerned, both choices could be largely independent of each other.

To my knowledge, there is no empirical research to date investigating how anticipations regarding future fertility influence the partnership formation processes. To fill this research gap, this study uses prospective data from $n=3,802$ childless respondents ( $n=14,572$ observation periods between waves) of the German Family Panel (pairfam). It analyses how anticipations of future fertility collected in one wave of the panel influence the risk of transitioning to a romantic or coresidential partnership by the next wave of the panel, using Cox regression models. It is assumed that the anticipation of fertility in general, as well as the anticipated timing of fertility, increase transition risks.

\section{Background and hypotheses}

\subsection{Theoretical background}

Recent theoretical approaches within life course research place more emphasis on agency, conceptualizing actors as actively trying to maximise their individual welfare/well-being through coordinated action across various life course domains and time (e.g. Bernardi et al. 2019; Buhr/Huinink 2014; Huinink/Feldhaus 2009; Mayer 2019). These concepts resonate with theories on individualisation (e.g. Beck 1992; Ehrhardt/Kohli 2011) and institutionalisation of the life course (e.g. Kohli 1986, 2007), which assume an increasing need for reflexive planning within individual life courses (biographisation). Similarly, the increasing importance of post-materialistic goals, such as self-realisation, that are assumed in different theoretical approaches (e.g. van de Kaa 2001; Lesthaeghe 2010, 2011; Inglehart/Welzel 2005) suggests that the role of actors (i.e. the "selves") needs to be taken into account more seriously. Concepts of the growing differentiation of private lives (Meyer 1992, 2014) also highlight the fact that individuals are likely to pursue different goals within their private lives and thus need to actively decide which goals to pursue and how. Finally, Becker's (1981) seminal work stresses the importance of considering economic constraints within households and families. Here, families and individuals, among other parties, are forced to weigh up different (life course) goals and to consider the consequences that pursuing goals in one life course domain (e.g. childbearing) will have on other life course domains (e.g. working life, such as in terms of opportunity costs).

In this context, Huinink and Kohli (2014) highlighted the need to conceptualise and analyse fertility within the life course paradigm in a more comprehensive manner. In their eyes, this could help to improve understanding of how fertility relates to developments in other life course domains, for example partnership and working life. Huinink and Feldhaus (2009: 317-318) furthermore assume that the "shadow of the future" - in the form of expectations, intentions or desires for core family-related events like childbirths - is likely to have a significant influence on 
decision-making in the near future. They argue that individuals try to take actions which lead to life course situations that are compatible with longer-term or general life course goals. Events in one life course dimension can thus be instrumental for reaching goals in other life course dimensions (Huinink/Fe/dhaus 2009: 309). In the case of fertility, individuals often assume a stable partnership (ideally in a shared apartment, i.e. coresidential) to be a prerequisite for childbearing (e.g. Berrington 2001, 2004; Rijken/Thomson 2011; Spéder/Kapitány 2009).

Empirical results on this question could also help to enhance our understanding of life course dynamics in general, and in particular interdependencies between life course dimensions, as suggested in established works by Elder (1985) and Levy (1977) for example. They could also help to improve understanding of the role played by individual strategies in maximizing well-being within life courses and thus contribute to the more general discussion about the role of agency and structure with respect to life course outcomes (Settersten/Gannon 2005; Huinink/Fe/dhaus 2009; Mayer 2019).

\subsection{Fertility orientations}

Some strands of theory (e.g. Heckhausen/Heckhausen 2010, 2018; Ajzen 1991; Miller 1994; Beckmann/Heckhausen 2018) suggest that a distinction should be drawn between expectations (subjective assessment of life course situations), intentions (goals or plans) and desires (internal individual preferences). There is, however, evidence that individuals do not clearly differentiate between these concepts (Wilson/Oeppen 2003; Davis/Warshaw 1992; Ní Bhrolcháin/Beaujouan 2019). Instead, they are seemingly intertwined and are likely to be represented in an individual's mind as more diffuse biographical orientations (Huinink/Kohli 2014; Van de Kaa 2001). I will term these fertility orientations when they refer to anticipated future fertility. Prior research on different topics, for example by Willoughby (2014), Carroll et al. (2007), Born (2001), Krüger (2014) and Wagner et al. (2019a), showed that biographical orientations for the longer-term influence the present and the shorter-term in many different dimensions of the life course.

I conceptualise fertility orientations to be part of biographical orientations. As suggested by Huinink and Kohli (2014: 1302-1303) these are established individually, based on beliefs, experiences and preferences, and influence further life course events. In accordance with the concepts established by Van de Kaa (2001), I also assume that individual orientations specifically with respect to fertility (but potentially also to other aspects) guide individuals in their decision-making across the life course, thus helping to form an individual lifestyle and an individual identity. The concept of biographical orientations is somewhat different to the concepts of schemas and life course scripts (Johnson-Hanks et al. 2011; Huinink/Kohli 2014; Macmillan/Copher 2005) because it reflects individual desires and intentions and is hence generated within individual minds. In contrast, schemas and scripts are defined as generally accepted ways of thinking and acting, generated and reproduced by reiterations of behaviour. They exist independently of individuals and are therefore part of the social structure. Biographical orientations may help 
individuals to coordinate actions within multiple time dimensions and periods within the life course, so that decisions in the present or in one life course dimension do not hinder goal attainment in the future or in other life course dimensions (Huinink/ Kohli 2014; Macmillan/Copher 2005).

I conceive fertility orientations as containing expectations, intentions and desires but being more general than these. I think of fertility orientations as anticipations, estimations, assumptions, prospects or forecasts of future fertility and as multidimensional constructs that encompass a number of different aspects (e.g. Ajzen 1991; Barrett et al. 2004; Miller 1994; Santelli et al. 2009). I distinguish between general orientations (no children vs. any number of children at any time) and a specific orientation with respect to the timing of fertility. These aspects are mentioned in several of the studies listed above and can therefore be regarded as key dimensions of fertility orientations. Other dimensions might exist, for instance with respect to parity or the preferred circumstances for childbearing. Findings from earlier research (Ruckdeschel et al. 2018; Schröder et al. 2016) suggest that most respondents will anticipate having two children, because of the strong twochild norm in Germany. Therefore, although it may be different in other countries, including parity into the analysis in Germany does not seem useful.

Fertility orientations are often geared towards the longer term and the inherent goals cannot be achieved within short time frames, especially for those individuals without a partner. The influence of fertility orientations on goals in other life course dimensions might even be greater than on fertility itself. This might be due to the fact that fertility intentions are frequently corrected if individuals grow older, not only if the desired circumstances have not yet been achieved (Verweij et al. 2020). Accordingly, previous studies demonstrated that fertility intentions for the near future increase the likelihood of residential relocation (Clark/Onaka 1983; Michielin) Mulder 2008; Vidal et al. 2017). Among individuals in their mid-twenties or thirties, the intention to have a child also influences the likelihood that a person will move in with their partner (Wagner et al. 2019a/b). Earlier studies also demonstrated that fertility intentions and the related expected family tasks influence the selection of professional pathways among women long before children are born (Born 2001; Krüger 2014; Zimmermann 2019).

Recent theoretical approaches assume that individuals construct fertility intentions and preferences in the interview situation and are strongly influenced by specific conditions and societal circumstances at the time of the interview (e.g. Bachrach/Morgan 2013; Ní Bhrolcháin/Beaujouan 2019; Philipov/Bernardi 2011; Rackin/Bachrach 2016; Schaeffer/Thompson 1992). Furthermore, they emphasise that fertility orientations are influenced by individual experiences and changes in one's own life course situations, as well as those of significant others, and are therefore likely to be adapted continuously throughout the life course (Gray et al. 2013; Kuhnt/Trappe 2016; Kuhnt et al. 2020; Miller 1994; Morgan 1981; Smith et al. 2020; Verweij et al. 2020). Consequently, these approaches and results suggest that fertility orientations should only be used when forecasting developments in the near future, not events or developments over the longer term. Panel data where the interval between data collections is short (e.g. one year, as used in the German 
Family Panel) is therefore especially suited to testing the influence of fertility orientations on partnership behaviour in the near future.

Prior theoretical concepts and empirical results also suggest that "being uncertain" is a crucial state and stage within the fertility decision-making process, and should be taken into account in research (Bernardi et al. 2015; Berrington 2004; Bachrach/ Morgan 2013; Ní Brolcháin et al. 2010; Kuhnt et al. 2020; Miettinen/Paajanen 2005; Morgan 1981, 1982; Ní Brolcháin/Beaujouan 2019; Schaeffer/Thompson 1992; Sobotka 2009). Prior results suggest that uncertainty about future fertility is high in particular among those individuals who are unmarried, partnerless and/or childless (Berrington 2004; Kuhnt/Buhr 2016; Kuhnt et al. 2020; Ní Bhrolcháin/Beaujouan 2011, 2015; Sobotka 2009) and that the prevalence of uncertainty differs by gender (Berrington 2004; Kuhnt/Buhr 2016; Miettinen/Paajanen 2005). As a result, in my analysis of fairly young, childless respondents, it is crucial to consider uncertainty as a category since it is likely to be mentioned frequently and indicates an important stage or step within the range of potential fertility orientations and their development across time.

\subsection{Forms of partnership and partnership formation}

An example of an event in one life course dimension being instrumental for another life course dimension is a partnership (ideally coresidential), which is often considered a prerequisite for childbearing (see for example Rijken/Thomson 2011; Spéder/Kapitány 2009; Berrington 2001). For the most part, Germans continue to regard marriage as a necessary or at least very useful prerequisite for childbearing (Konietzka/Kreyenfeld 2017). As Nave-Herz (2015) points out, within the context of "responsible parenthood", individuals often only consider marriage as an option if they are expecting children ("child-oriented marriage"). Marriage is thus deinstitutionalised, i.e. it is no longer mandatory for couples, nor does it continue to hold the same privileges that it once did compared with other partnership and family forms (Cherlin 2004; Coontz 2004; Lauer/Yodanis 2010; Thornton et al. 2007; Walker 2016).

The differentiation of partnership forms means that individuals often go through a number of stages in the process of institutionalising a partnership (Kopp et al. 2010). In recent years, this has mainly occurred in the order described below (Hoppmann/Zimmermann 2018; Konietzka/Zimmermann 2020). Individuals first find a partner, with whom a steady dating or Living-Apart-Together-partnership (LAT, Duncan/Phillips 2011; Levin/Trost 1999) is established. From now on, I will refer to this stage of the partnership formation process as entering, starting or transitioning to a romantic partnership. A romantic partnership is characterised by the fact that the partners define themselves as a couple and typically view intimacy as exclusive to their relationship.

After a while, partners might opt to share an apartment, i.e. coreside. From now on, I will refer to this stage of the partnership formation process as entering, starting or transitioning into a coresidential partnership. Marriage is often the final stage in the institutionalisation process. Historically, the stages would often occur 
Fig. 1: Illustration of partnership forms and transition patterns

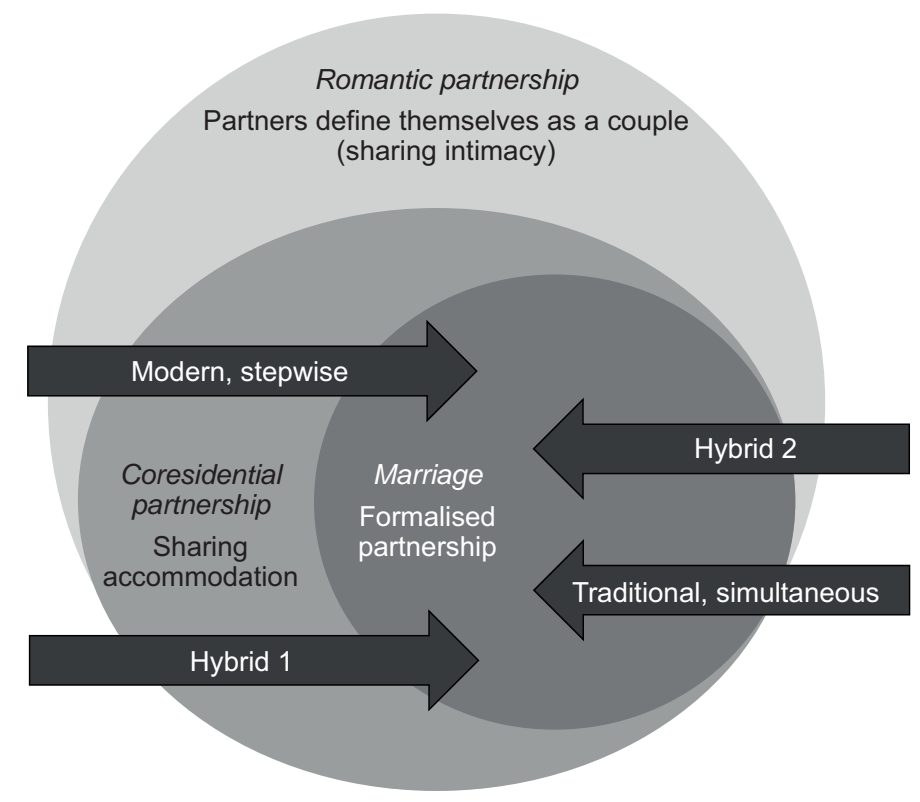

Source: Own design

at the same time (i.e. the date on which a couple married also marked the start of their coresidential and romantic partnership) and this can still happen today; in this case, the date of transition to a romantic partnership, coresidential partnership and marriage is the same. The transition to marriage is not considered in this study because the number of members in my sample undergoing the transition to marriage within the period analysed was too small.

Figure 1 shows that marriage, romantic partnerships and coresidential partnerships are not mutually exclusive but instead build upon one other. Marriage also implies the existence or start of a romantic and coresidential partnership, while a romantic partnership is a prerequisite for a coresidential partnership. The forms of partnership can be started simultaneously ("traditional" pattern) or consecutively ("modern" pattern of gradual institutionalisation). Hybrid forms of transitioning are also conceivable, in which either the transition to a romantic and coresidential partnership happens at the same time (hybrid 1) or marriage and transition to coresidence happen at the same time (hybrid 2). If the transition to a romantic or coresidential partnership takes place at the same time as any of the other events, these events shall still be counted as transitions to a romantic or coresidential partnership in the context of this research and the relevant respondents will thus form part of the respective data sets (see also the section on methodology). ${ }^{1}$

1 Please note that the hypothetical case of a couple getting married before starting a coresidential union hardly appears in empirical data and is therefore not considered here. 


\subsection{Hypotheses}

I assume that if fertility orientations include anticipations of fertility in the near future, the search for a partner and efforts to establish and institutionalise a partnership may be intensified. As a result, my expectation is that the number of years to pass until the assumed time of the first birth will have a strong and negative impact on the risk of transitioning to a romantic or coresidential partnership (hypothesis 1). Because changes in individual and societal circumstances are unpredictable, I also anticipate finding a high degree of uncertainty as regards expected fertility (Berrington/Pattaro 2014; Ní Bhrolcháin/Beaujouan 2019; Verweij et al. 2020). I assume that individuals who are uncertain about fertility in the future will be less likely to transition to a romantic or coresidential partnership than men or women with a clearer vision of their future (hypothesis 2). Furthermore, the likelihood of transitioning to a romantic or coresidential partnership ought to be even less among individuals who are not planning to have children at all (hypothesis 3 ) as the latter may prefer a greater degree of freedom in their lives. Hypothesis 3 reflects "general" fertility orientations (i.e. whether respondents on the whole anticipate having children, regardless of the assumed timing).

Among younger people, who make up the larger share of my sample, noncoresidential romantic partnerships might sometimes be less serious and be only trial partnerships (Lois 2012). Additionally, a coresidential partnership is regarded a specific requirement for childbearing (Berrington 2001; Rijken/Thomson 2011; Spéder/Kapitány 2009). I therefore expect all of the above mentioned factors (number of years until assumed fertility, uncertainty about anticipated fertility, general fertility orientations) to influence the transition to coresidential partnerships more strongly than the transition to a romantic partnership (hypothesis 4).

\section{$3 \quad$ Methodology}

\subsection{Data and variables}

I use data from waves 1-10 of the German Family Panel (pairfam, Huinink et al. 2011, data collected between 2008 and 2018, release 10.0; Brüderl et al. 2019). The biopart file contains information on partnership events on a monthly basis, which I combined with the information from the attitudinal and sociodemographic data collected in different waves (files anchor1-anchor9). Table 1 describes how the independent variables were measured and recoded for the analysis. I used questions on the "realistic" (not the "ideal") number and timing of births because answers are likely to be based on an evaluation of the preconditions or life course circumstances (i.e. expectations in expectancy-value models, Ajzen 1991; Heckhausen/Heckhausen 2010, 2018; Miller 1994). Furthermore, I assume that answers to these questions also reflect individual desires (internal individual preferences) and intentions (concrete goals or plans). The "realistic" number and timing of births therefore provide the best fit with the concept of fertility orientations. I merged the two categories "I'm 
Tab. 1: Measurements and recoding of aspects of fertility orientations for all childless respondents

\begin{tabular}{|c|c|c|c|}
\hline $\begin{array}{l}\text { Aspect } \\
\text { measured }\end{array}$ & Question \& variable & Possible responses & Transformations of variables \\
\hline $\begin{array}{l}\text { (1) General } \\
\text { fertility } \\
\text { orientation }\end{array}$ & $\begin{array}{l}\text { "When you think } \\
\text { realistically about } \\
\text { having children, how } \\
\text { many children do you } \\
\text { think you will have?" } \\
\text { (waves 1-2, frt6) } \\
\text { "When you think } \\
\text { realistically about } \\
\text { having children, how } \\
\text { many biological or } \\
\text { adoptive children do } \\
\text { you think you will } \\
\text { have?" (waves 3-9, } \\
\text { frt26) }\end{array}$ & $\begin{array}{l}\text { "one child", "two } \\
\text { children", "three } \\
\text { children", "four or } \\
\text { more children", "no } \\
\text { children", "I'm not } \\
\text { sure", "I have not } \\
\text { thought about that". }\end{array}$ & $\begin{array}{l}\text { Categories "no children", "I'm } \\
\text { not sure" and "I have not thought } \\
\text { about that" are used to form } \\
\text { the categories "no children" and } \\
\text { "uncertain" of the independent } \\
\text { variable. } \\
\text { Note: This variable was used } \\
\text { as a filter variable. Only } \\
\text { respondents who anticipate } \\
\text { having at least one child were } \\
\text { asked about what they perceive } \\
\text { to be a realistic time frame (frt9) }\end{array}$ \\
\hline (2) Timing & $\begin{array}{l}\text { "When you think } \\
\text { realistically about } \\
\text { having children, how } \\
\text { old do you think you } \\
\text { will be when you } \\
\text { have your first child?" } \\
\text { (frt9) }\end{array}$ & $\begin{array}{l}\text { age in years or "I have } \\
\text { not thought about } \\
\text { that". }\end{array}$ & $\begin{array}{l}\text { "uncertain" is inserted if } \\
\text { expressed either in this (frt9) } \\
\text { or the prior (filtering) question } \\
\text { on the number of children } \\
\text { anticipated (frt6/frt26; "I'm not } \\
\text { sure" or "I have not thought } \\
\text { about that"). "no children" } \\
\text { is inserted if mentioned in } \\
\text { the previous question on } \\
\text { parity. Calculation of years } \\
\text { until expected 1 1st childbirth } \\
\text { by subtracting the age of } \\
\text { respondents; categories "in the } \\
\text { next } 4 \text { years", "in } 5-6 \text { years", "in } \\
7-8 \text { years", "in } 9-10 \text { years" and "in } \\
\text { more than } 10 \text { years" are formed } \\
\text { based on the distribution of } \\
\text { respondents. }\end{array}$ \\
\hline
\end{tabular}

Note: As only childless respondents are included in the analysis, variations of the questions (next instead of first child, additional children instead of children) are not relevant for the samples.

1 German original: "Wenn Sie einmal realistisch über eigene Kinder nachdenken: Wie viele Kinder denken Sie, werden Sie haben?" (waves 1-2) "Wenn Sie einmal realistisch über Kinder nachdenken: Wie viele leibliche Kinder oder Adoptivkinder, denken Sie, werden Sie haben?" (waves 3-9); answer options: "Ein Kind" / "Zwei Kinder" / "Drei Kinder" / "Vier Kinder und mehr" "Ich bin mir nicht sicher" / "Darüber habe ich mir noch keine Gedanken gemacht" / "Kein Kind".

2 German original: "Wenn Sie einmal realistisch über eigene Kinder nachdenken: In welchem Alter denken Sie, werden Sie Ihr erstes Kind bekommen?", answer options: "Mit __ Jahren" / "Darüber habe ich mir noch keine Gedanken gemacht".

Source: German Family Panel Scales and Instruments Manual, Release 10.0 (Thönnissen et al. 2018), own considerations. 
not sure" and "I have not thought about that" since the first option was only chosen by a small number of the young, partnerless individuals included in the sample. I also believe that, for the purpose of my analysis, these two categories actually have the same meaning: the respondent is not (yet) clear about his/her fertility intentions.

As described above, I expect that fertility orientations may change based on the experiences of the respondents. It is therefore useful to model transition risks based on fertility-related attitudes surveyed not long before the events occur, if they do in fact occur at all. I meet this requirement by analysing transition risks between each pair of waves of the panel data provided. Thus, I model the influences that attitudes measured in the interview of any wave i have on transition risks until the next interview in wave $i+1$. The observation periods are around twelve months long, but differ slightly in length according to the exact timing of the interviews of each respondent within the waves. The biopart file was in this sense used to create a data set $A$, including all partnerless and childless respondents in wave $i$ (1 to 9 ) in order to analyse transitions to a romantic or coresidential partnership until the subsequent wave $i+1$. An additional data set $B$ includes all respondents without a coresidential partnership or children, regardless of whether they are in a romantic partnership, in order to analyse transitions to coresidential partnership. Married individuals are usually in a romantic partnership and coreside and are therefore not part of the samples. Individuals under the age of 18 (formal adulthood in Germany) are not included in the sample because they are not yet able to take full responsibility for any children of their own or other important life course decisions: their fertility orientations are therefore expected to be less meaningful.

Respondents who participated in more than two waves in the German Family Panel might be included more than once in the data sets. Observation periods for which there was no information on the independent and control variables, or for which respondents already had a child at the beginning of the analysis period, were dropped. Figure 2 provides an overview of the distribution of the observation periods between waves 1 and 10 of the German Family Panel and the total number of observations in each of the data sets.

Transition risks to a romantic and coresidential partnership are the dependent variable; see chapter 2 for details on the definition of these forms of partnership. If these or other partnership transitions occur within the same month, both transitions are assumed to have happened. I have integrated the following sociodemographic variables as covariates in the models, for which prior research or theoretical considerations proved or suggested influences on partnership formation. The region (East/West Germany) is important because family formation cultures are still very different in both parts of the country (e.g. Raab 2017). The size of the community (five categories) is included since this has a considerable influence on the partners that are available within a reachable distance, i.e. the partnership market. The migration status (second generation migrant or not, with first generation migrants having been excluded) is relevant because it can also determine partnership and family formation values as well as social contacts. The activity status (in education, regular full-time employment, other form of employment, not employed; recode of variable casprim) is relevant as prior research also showed that being in education, precarious 
Is Early Partnership Formation Instrumental for Fertility in Germany? •

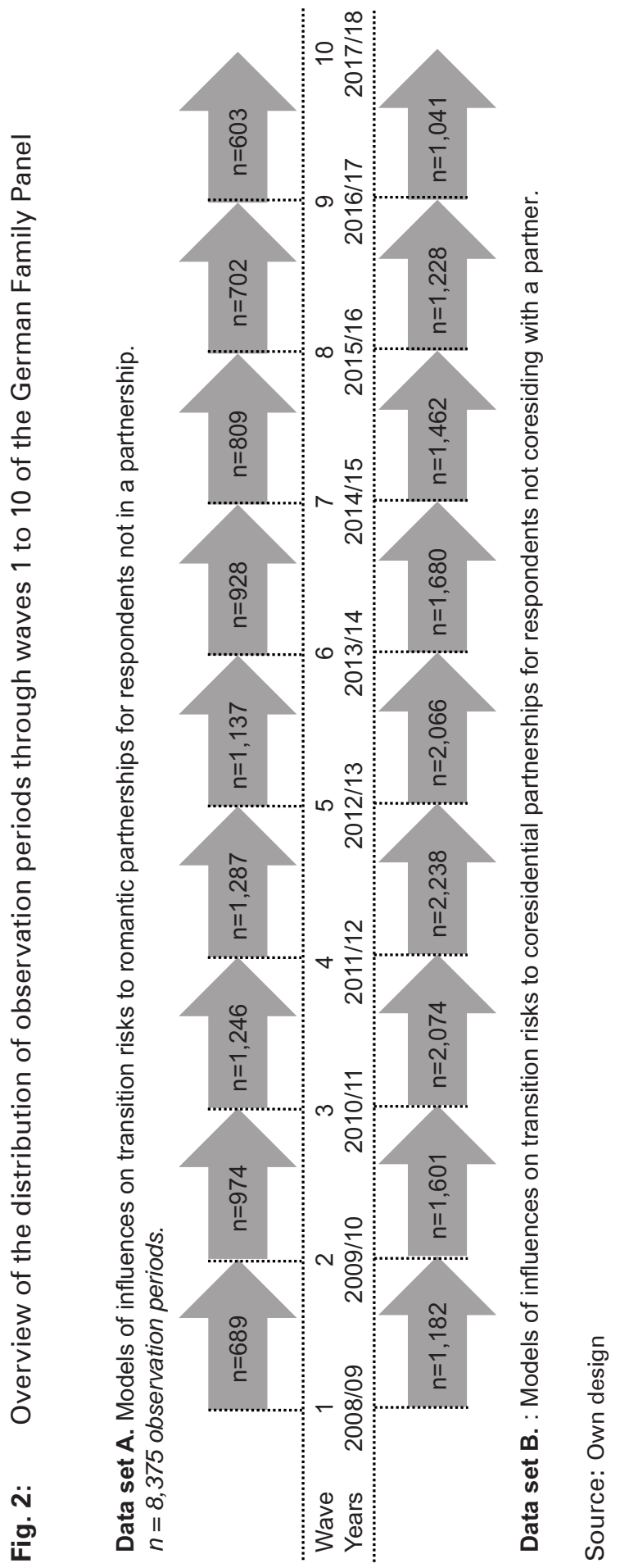


employment or being unemployed are factors that can influence partnership transitions (e.g. Andersen/Özcan 2021; Heintz-Martin/Zabel 2019; Liefbroer et al. 2015; Schmitt 2021). Partnership transitions are likely to be influenced by age (e.g. Gray et al. 2013; Wagner et al. 2019a/b). Health is an important predictor of the likelihood of entering cohabitation (Brown et al. 2012) and is therefore included. The relationship status (single, romantic partnership; only in models analysing transition risks to a coresidential partnership) is necessary as a covariate because individuals in romantic partnerships are more likely to transition to a coresidential partnership than those without a partner (Kopp et al. 2010).

\subsection{Analytical approach}

I use event history analysis in Stata to analyse what influence the different aspects of the fertility orientations have on the transition to romantic or coresidential partnerships. I apply multi-level Cox proportional hazard regression models for single destinations (Cox 1972). After calculating the regression models, I tested the proportional hazards assumption based on Schoenfeld residuals (Schoenfeld 1982). The influences that different aspects of fertility orientations measured in wave i (1 to 9) have on the risk of transitioning to a romantic partnership or institutionalizing the partnership further by way of coresidence can be identified using Cox models. For those respondents who did not experience the respective transition until wave $i+1$, the data is indicated as being censored at the time of the interview in wave $i+1$ and included in the analysis.

I accounted for frailty of observations from the same individual (by grouping these observations using Stata's "shared" option, i.e. applying a multi-level model) and for period effects using a variable on the wave at the beginning of the observation period as a control variable. I can therefore control for effects of changing institutional circumstances (e.g. changes in housing costs, economic upswing and downturn that might affect fertility intentions, see Comolli 2021). I included the independent variable in a categorical form, so that the category "uncertain" could be kept. For a robustness check, I excluded uncertain respondents so as to be able to create a continuous independent variable.

Importantly, using panel data for the analysis helps to avoid causality problems (Brüderl 2010) because the independent variable (in this case the anticipation of fertility) is measured before the dependent variable (in this case a dependent event, namely the transition to a romantic or coresidential partnership) within the chronological life course of individuals. Specifically, I use the anticipation of fertility (estimates of "realistic" fertility) in wave i to forecast partnership events until wave $i+1$, which are retrospectively reported in wave $i+1$ (i.e. about a year after the fertility orientations). Working on the assumption that the forecasting of future events (in this case partnership transitions) is always very uncertain and therefore unlikely to influence anticipations of fertility measured before such transitions, problems of reverse causality are therefore improbable. In the limitations, I discuss the unlikely circumstances under which reverse causality may still occur within this analytical framework and the consequences thereof for my results. 


\section{Results}

\subsection{Descriptive findings}

If respondents are partnerless in wave $\mathrm{i}$, the proportion of them transitioning to a romantic partnership by the next wave $i+1$ is slightly less than half (Fig. 3 ). A quarter of respondents without a coresidential partnership in wave i transition to a coresidential partnership by wave i+1 (Fig. 4). In line with prior results, women experience partnership transitions at a slightly faster rate than men, which also explains why there are more men than women in my data sets.

Table 2 displays descriptive results for the independent and control variables for the two data sets for all observation periods, with many respondents included in the sample more than once. In more than a third of the observation periods, the assumption among respondents was that it would be seven years or more before they have children (measured at the beginning of the observation period). Depending on sex and partnership status, the anticipation among respondents in around a fifth of all observation periods is that they will have children within the next four years (i.e. in the near future). For many of the observation periods, the

Fig. 3: Transition risks to a romantic partnership

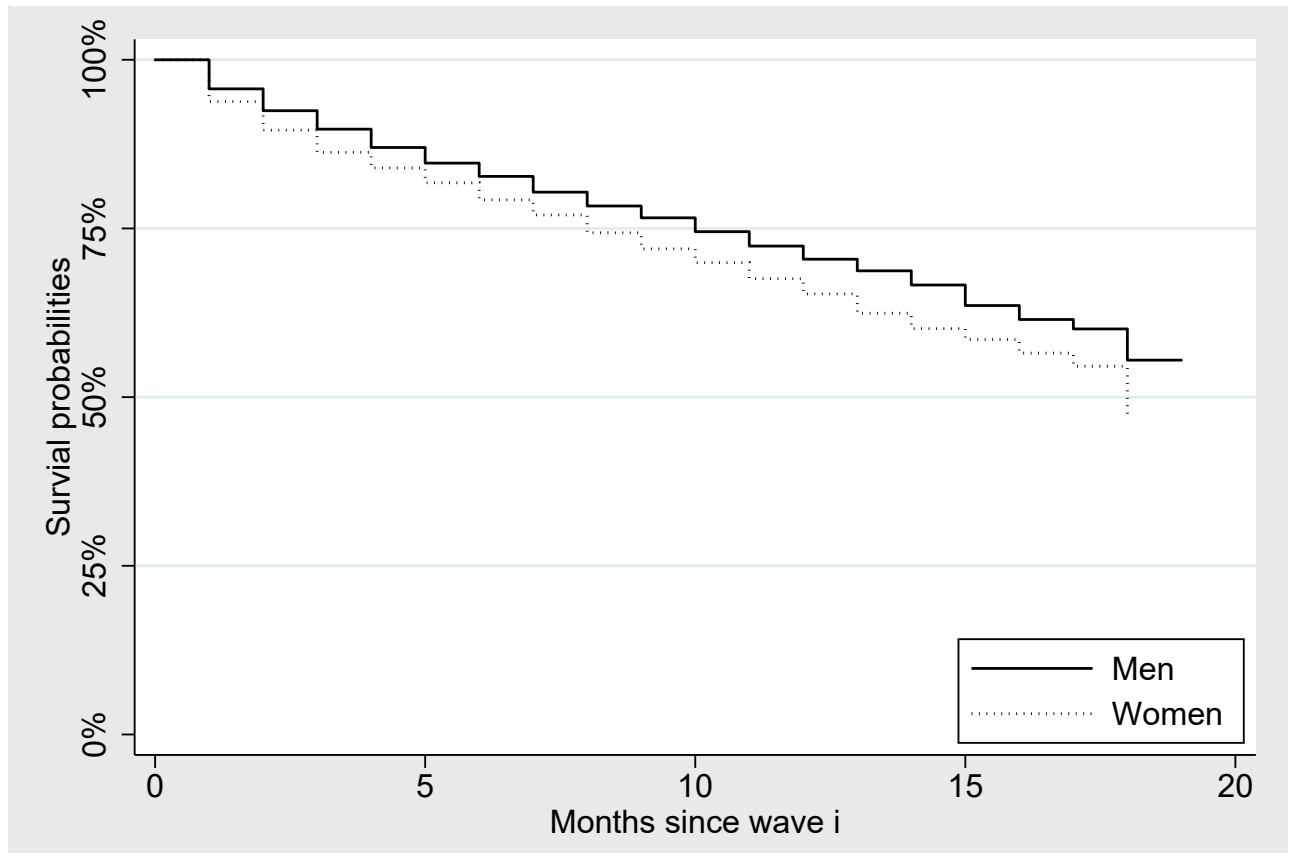

Kaplan-Meier survival estimates for the transition to a romantic partnership between waves $i$ and $i+1$. Based on 8,375 observation periods $(3,405$ of women, 4,970 of men) of 2,854 respondents (1,238 women, 1,616 men).

Source: German Family Panel waves 1-10, own calculations. 
Fig. 4: Transition risks to a coresidential partnership

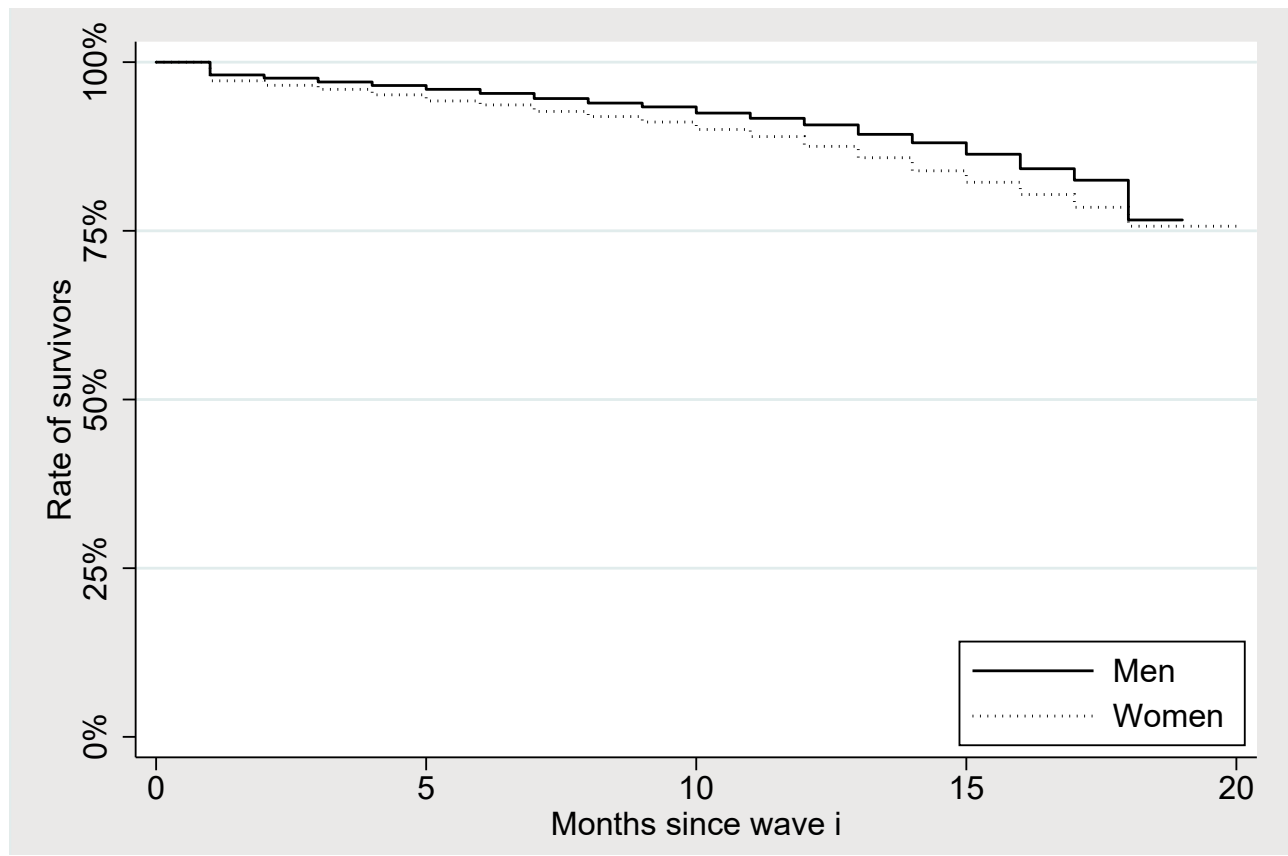

Kaplan-Meier survival estimates for the transition to a coresidential partnership between waves $i$ and $i+1$. Based on 14,572 observation periods (6,503 of women, 8,069 of men) of 3,802 respondents (1,753 women, 2,049 men).

Source: German Family Panel waves 1-10, own calculations.

respondents live in small towns (fewer than 20,000 inhabitants). Respondents are still in education at the beginning of more than half of the observation periods. This is likely a result of the fact that the average age is low $(24$ to 25 years depending on the sub-sample), with there being many young respondents in the sample. This can in turn be attributed to most respondents among the older cohorts having already experienced the transitions examined and thus being excluded from the data sets. At the beginning of around a third of the observation periods, the respondents reported being in regular full-time employment, with other types of employment and non-employment accounting in equal measure for the remainder of the observation periods. Depending on sex and partnership status, the respondents in 12-15 percent of the observation periods were $2^{\text {nd }}$ generation migrants and nearly a quarter of the observation periods stem from respondents from East Germany. At the beginning of some 30 percent of the observation periods, the male respondents in question reported poor health. This figure was higher for women, with poor or satisfactory health being reported at the beginning of 37-38 percent of observation periods. 
Tab. 2: Descriptive results (measured at the beginning of the observation periods)

\begin{tabular}{|c|c|c|c|c|}
\hline & \multicolumn{2}{|c|}{$\begin{array}{l}\text { Data Set A } \\
\text { All respondents not in a } \\
\text { romantic partnership }\end{array}$} & \multicolumn{2}{|c|}{$\begin{array}{l}\text { Data Set B } \\
\text { All respondents not in a } \\
\text { coresidential partnership }\end{array}$} \\
\hline & $\begin{array}{c}\text { Women } \\
(3,405 \text { obs. })\end{array}$ & $\begin{array}{c}\text { Men } \\
(4,970 \text { obs.) }\end{array}$ & $\begin{array}{c}\text { Women } \\
(6,503 \text { obs.) }\end{array}$ & $\begin{array}{c}\text { Men } \\
(8,069 \text { obs.) }\end{array}$ \\
\hline \multicolumn{5}{|c|}{ Realistic timing of first child (recode of frt9) } \\
\hline No children & $526(15 \%)$ & $495(10 \%)$ & $742(11 \%)$ & $703(9 \%)$ \\
\hline In the next 4 years & $715(21 \%)$ & $868(17 \%)$ & $1,543(24 \%)$ & $1,682(21 \%)$ \\
\hline In 5-6 years & $636(19 \%)$ & $856(17 \%)$ & $1,298(20 \%)$ & $1,498(19 \%)$ \\
\hline In 7-8 years & $540(16 \%)$ & $800(16 \%)$ & $1,157(18 \%)$ & $1,283(16 \%)$ \\
\hline In $9-10$ years & $356(10 \%)$ & $524(11 \%)$ & $716(11 \%)$ & $866(11 \%)$ \\
\hline In more than 10 years & $206(6 \%)$ & $449(9 \%)$ & $383(6 \%)$ & $662(8 \%)$ \\
\hline Uncertain & $426(13 \%)$ & $978(20 \%)$ & $664(10 \%)$ & $1,375(17 \%)$ \\
\hline \multicolumn{5}{|c|}{ Realistic timing of first child (recode of frt9) ${ }^{1}$} \\
\hline Years until birth of first child & 6.33 & 6.84 & 6.23 & 6.56 \\
\hline \multicolumn{5}{|l|}{ Migration background } \\
\hline No migration Background & $2,889(85 \%)$ & $4,388(88 \%)$ & $5,619(86 \%)$ & $7,143(89 \%)$ \\
\hline $2^{\text {nd }}$ generation migrants & $516(15 \%)$ & $582(12 \%)$ & $884(14 \%)$ & $926(11 \%)$ \\
\hline \multicolumn{5}{|l|}{ Community size } \\
\hline$<5,000$ & $399(12 \%)$ & $796(16 \%)$ & $815(13 \%)$ & $1,212(15 \%)$ \\
\hline $5,000-20,000$ & $888(26 \%)$ & $1,501(30 \%)$ & $1,865(29 \%)$ & $2,394(30 \%)$ \\
\hline $20,000-50,000$ & $620(18 \%)$ & $861(17 \%)$ & $1,204(18 \%)$ & $1,444(18 \%)$ \\
\hline $50,000-100,000$ & $308(9 \%)$ & $429(9 \%)$ & $564(9 \%)$ & 737 (9\%) \\
\hline $100,000-500,000$ & $586(17 \%)$ & $751(15 \%)$ & $1,044(16 \%)$ & $1,256(16 \%)$ \\
\hline $500,000+$ & $604(18 \%)$ & $632(13 \%)$ & $1,011(16 \%)$ & $1,026(13 \%)$ \\
\hline \multicolumn{5}{|l|}{ Region } \\
\hline West & $2,712(80 \%)$ & $3,766(76 \%)$ & $5,155(79 \%)$ & $6,280(78 \%)$ \\
\hline East & $693(20 \%)$ & $1,204(24 \%)$ & $1,348(21 \%)$ & $1,789(22 \%)$ \\
\hline \multicolumn{5}{|l|}{ Health } \\
\hline Poor/satisfactory (0) & $1,308(38 \%)$ & $1,554(31 \%)$ & $2,420(37 \%)$ & $2,342(29 \%)$ \\
\hline Good/very good (1) & $2,097(62 \%)$ & $3,416(69 \%)$ & $4,083(63 \%)$ & $5,727(71 \%)$ \\
\hline \multicolumn{5}{|c|}{ Activity status (recode of casprim) } \\
\hline In education & $1,837(54 \%)$ & $2,442(49 \%)$ & $3,763(58 \%)$ & $4,198(52 \%)$ \\
\hline Regular full-time employment & $1,043(31 \%)$ & $1,734(35 \%)$ & $1,815(28 \%)$ & $2,707(34 \%)$ \\
\hline Other type of employment ${ }^{2}$ & $297(9 \%)$ & $393(8 \%)$ & $536(8 \%)$ & $606(7 \%)$ \\
\hline Not employed ${ }^{3}$ & $228(7 \%)$ & $401(8 \%)$ & $389(6 \%)$ & $558(7 \%)$ \\
\hline \multicolumn{5}{|c|}{$\begin{array}{l}\text { For a smaller sample as respondents who are "uncertain" are excluded. Sample sizes: Model a } \\
\text { (women)-2,453; Model b (men) - 3,497; Model c (women) - 5,097; Model d (men) 5,991. }\end{array}$} \\
\hline \multicolumn{5}{|c|}{$\begin{array}{l}\text { Including self-employment, part-time employment, marginal employment, internships, other } \\
\text { irregular employment, military and civilian service. }\end{array}$} \\
\hline 3 Including maternal or paternal & leave, retireme & t disability iobl & ssness. & \\
\hline
\end{tabular}


Tab. 2: Continuation

\begin{tabular}{lcccc}
\hline \multicolumn{2}{c}{ Data Set A } & \multicolumn{2}{c}{ Data Set B } \\
& All respondents not in a & All respondents not in a \\
romantic partnership & Coresidential partnership \\
Women & Men & Women & Men \\
& $(3,405$ obs.) & $(4,970$ obs.) & $(6,503$ obs.) & $(8,069$ obs.) \\
\hline Wave & & & & \\
1 & $261(8 \%)$ & $428(9 \%)$ & $471(7 \%)$ & $711(9 \%)$ \\
2 & $402(12 \%)$ & $572(12 \%)$ & $697(11 \%)$ & $904(11 \%)$ \\
3 & $499(15 \%)$ & $747(15 \%)$ & $918(14 \%)$ & $1,156(14 \%)$ \\
4 & $535(16 \%)$ & $752(15 \%)$ & $1,040(16 \%)$ & $1,198(15 \%)$ \\
5 & $473(14 \%)$ & $664(13 \%)$ & $953(15 \%)$ & $1,113(14 \%)$ \\
6 & $368(11 \%)$ & $560(11 \%)$ & $756(12 \%)$ & $924(11 \%)$ \\
7 & $331(10 \%)$ & $478(10 \%)$ & $666(10 \%)$ & $796(10 \%)$ \\
8 & $290(9 \%)$ & $412(8 \%)$ & $542(8 \%)$ & $686(8 \%)$ \\
9 & $246(7 \%)$ & $357(7 \%)$ & $460(7 \%)$ & $581(7 \%)$ \\
Partnership status & & & & \\
Not in a partnership & $100 \%$ & $100 \%$ & $3,405(52 \%)$ & $4,970(62 \%)$ \\
In a romantic partnership & - & - & $3,098(48 \%)$ & $3,099(38 \%)$ \\
Age (mean) & 24.99 & 25.41 & 24.03 & 25.00 \\
\hline
\end{tabular}

Base: Observation periods (not respondents), i.e. many respondents appear more than once in the results with the answers given in the wave before the observation period reported.

Source: German Family Panel (pairfam) waves 1-10, own calculations.

\subsection{Cox regression models}

Table 3 summarises the results of the different regression models. It is plausible and in line with prior findings for some of the covariates, mainly age, partnership status (for models $\mathrm{c}$ and $\mathrm{d}$ only) and activity status (for transition in coresidential partnership only) to influence transition rates.

Consistent with the assumption under hypothesis 1, the risk of transitioning to a romantic or coresidential partnership decreased in line with the length of time that needs to pass until the reported "realistic" age of fertility. The transition risks are highest in all models for those who expect to have children within the next four years and decline continuously where respondents anticipate more years to pass before the birth of a child. The sensitivity models (appendix table A1) using a continuous model support the assumption of a clear, and what is likely to be an almost linear effect of the time that respondents expect to pass until childbearing. The effects are even greater for the transition to coresidential partnerships, which is consistent with the results from previous research indicating that coresidence is often considered a prerequisite for childbearing. For women, the effects of fertility anticipated for the near future in terms of transition to a romantic partnership are not significant for the most part; in case the differences are significant, the corresponding confidence 
Tab. 3: Results of Cox proportional hazard regression models for single destinations (Cox 1972)

\begin{tabular}{|c|c|c|c|c|}
\hline \multirow{2}{*}{$\begin{array}{l}\text { Influences on transition } \\
\text { risks of the anticipated } \\
\text { time until the birth of } 1^{\text {st }} \text { child }\end{array}$} & \multicolumn{2}{|c|}{$\begin{array}{l}\text { Transition to romantic } \\
\text { partnership (data-set A) }\end{array}$} & \multicolumn{2}{|c|}{$\begin{array}{l}\text { Transition into coresidential } \\
\text { partnership (data-set B) }\end{array}$} \\
\hline & $\begin{array}{c}\text { Women } \\
\text { (a) } \\
\text { Obs.3,405 } \\
\text { Resp. 1,238 } \\
\text { Trans. 1,274 } \\
\text { Prob>Chi' } .000\end{array}$ & $\begin{array}{c}\text { Men } \\
\text { (b) } \\
\text { Obs 4,970 } \\
\text { Resp. 1,616 } \\
\text { Trans. 1,564 } \\
\text { Prob>Chi }{ }^{2} .000\end{array}$ & $\begin{array}{c}\text { Women } \\
\text { (c) } \\
\text { Obs. } 6,503 \\
\text { Resp. 1,753 } \\
\text { Trans. } 932 \\
\text { Prob>Chi }{ }^{2} .000\end{array}$ & $\begin{array}{c}\text { Men } \\
\text { (d) } \\
\text { Obs. } 8,069 \\
\text { Resp. } 2,049 \\
\text { Trans. } 872 \\
\text { Prob>Chi }{ }^{2} .000\end{array}$ \\
\hline No children & $.640 * *$ & $.626^{* * *}$ & $.393^{* * *}$ & $.522 * * *$ \\
\hline In the next 4 years & [reference] & [reference] & [reference] & [reference] \\
\hline In 5-6 years & $.807^{*}$ & $.724^{* * *}$ & $.569 * * *$ & $.560 * * *$ \\
\hline In 7-8 years & .833 & $.659 * * *$ & $.464^{* * *}$ & $.421^{* * *}$ \\
\hline In $9-10$ years & .788 & $.613^{* * *}$ & $.344^{* * *}$ & $.241 * * *$ \\
\hline In more than 10 years & $.713^{*}$ & $.563^{* * *}$ & $.312^{* * *}$ & $.175^{* * *}$ \\
\hline Uncertain & $.876^{*}$ & $.623^{* * *}$ & $.560 * * *$ & $.521 * * *$ \\
\hline \multicolumn{5}{|c|}{ Migration status [reference: no migration background] } \\
\hline $2^{\text {nd }}$ generation migrant & 1.102 & 1.043 & .921 & .841 \\
\hline \multicolumn{5}{|l|}{ Region [ref.: West] } \\
\hline East & 1.146 & 1.034 & 1.180 & .993 \\
\hline \multicolumn{5}{|c|}{ Size of community [reference: $5,000-<20,000]$} \\
\hline $500,000+$ & .851 & 1.206 & .960 & 1.009 \\
\hline $100,000-<500,000$ & .961 & 1.100 & 1.051 & 1.059 \\
\hline $50,000-<100,000$ & 1.034 & 1.213 & 1.097 & .797 \\
\hline $20,000-<50,000$ & $.794^{*}$ & 1.129 & 1.088 & $1.305^{*}$ \\
\hline$<5,000$ & .972 & 1.011 & 1.156 & 1.029 \\
\hline Good health & .981 & 1.049 & .960 & 1.045 \\
\hline \multicolumn{5}{|c|}{ Activity status [reference: in education] } \\
\hline Regular full-time employment & 1.092 & 1.098 & $1.642^{* * *}$ & $1.594^{* * *}$ \\
\hline Other employment ${ }^{1}$ & 1.073 & .941 & $1.423^{* *}$ & $1.417^{*}$ \\
\hline Not employed ${ }^{2}$ & .761 & $.742^{*}$ & 1.341 & 1.041 \\
\hline Age & $.958 * * *$ & $.966 * * *$ & .984 & 1.015 \\
\hline
\end{tabular}




\section{Tab. 3: Continuation}

\begin{tabular}{|c|c|c|c|c|}
\hline \multirow{2}{*}{$\begin{array}{l}\text { Influences on transition } \\
\text { risks of the anticipated } \\
\text { time until the birth of } 1^{\text {st }} \text { child }\end{array}$} & \multicolumn{2}{|c|}{$\begin{array}{l}\text { Transition to romantic } \\
\text { partnership (data-set A) }\end{array}$} & \multicolumn{2}{|c|}{$\begin{array}{l}\text { Transition into coresidential } \\
\text { partnership (data-set B) }\end{array}$} \\
\hline & $\begin{array}{c}\text { Women } \\
\text { (a) } \\
\text { Obs.3,405 } \\
\text { Resp. 1,238 } \\
\text { Trans. 1,274 } \\
\text { Prob>Chi }{ }^{2} .000\end{array}$ & $\begin{array}{c}\text { Men } \\
\text { (b) } \\
\text { Obs 4,970 } \\
\text { Resp. 1,616 } \\
\text { Trans. 1,564 } \\
\text { Prob>Chi }{ }^{2} .000\end{array}$ & $\begin{array}{c}\text { Women } \\
\text { (c) } \\
\text { Obs. 6,503 } \\
\text { Resp. 1,753 } \\
\text { Trans. } 932 \\
\text { Prob>Chi } .000\end{array}$ & $\begin{array}{c}\text { Men } \\
\text { (d) } \\
\text { Obs. 8,069 } \\
\text { Resp. 2,049 } \\
\text { Trans. } 872 \\
\text { Prob>Chi }{ }^{2} .000\end{array}$ \\
\hline \multicolumn{5}{|l|}{ Wave [reference: wave 1] } \\
\hline 2 & .973 & 1.054 & .938 & .951 \\
\hline 3 & .947 & 1.093 & .819 & 1.033 \\
\hline 4 & .877 & 1.078 & $.734^{*}$ & .965 \\
\hline 5 & .848 & .991 & $.707^{*}$ & .905 \\
\hline 6 & .795 & .900 & .948 & 1.101 \\
\hline 7 & .829 & .974 & 1.120 & 1.157 \\
\hline 8 & .912 & .849 & 1.224 & 1.178 \\
\hline 9 & .892 & 1.016 & .810 & 1.186 \\
\hline
\end{tabular}

Relationship status [reference: not in a partnership, models $c$ and $d$ only]

$\begin{array}{lllll}\text { In a romantic partnership } & - & - & 4 & 4.051^{* * *}\end{array}$

Obs $=$ number of observation periods; Resp $=$ number of respondents; Trans $=$ number of transitions in the sample; ${ }^{*} \mathrm{p}<.05,{ }^{*} \mathrm{p}<.01,{ }^{* * *} \mathrm{p}<.001$; Prob $>$ Chi2 $>.05$ in all tests of proportional hazards assumption based on Schoenfeld residuals. Models include controls for frailty (observations from the same individual) and period effects (wave), region (East/West Germany), size of the community, migration status $\left(2^{\text {nd }}\right.$ generation migrant or not; $1^{\text {st }}$ generation migrants excluded from analysis), activity status, age, health status. Models $\mathrm{c}$ and $\mathrm{d}$ include controls for partnership status (not in a partnership vs. in a romantic partnership). Models with continuous variable only as robustness check in appendix.

Source: German Family Panel (pairfam) waves 1-10, own calculations.

level is low and the effect sizes are small. Thus, there is less support for hypothesis 1 among women, especially with regard to the transition to a romantic partnership.

Consistent with my expectations under hypothesis 2, uncertainty about the timing of fertility was negatively related to transitions to romantic and coresidential partnerships, especially among men, but also among women. I found that results supported my assumption under hypothesis 3 , namely that the risk of transitioning to a romantic partnership decreased where respondents had no intention to have children. The influence of this factor was greater than that of uncertainty, albeit only among women. Among men, uncertainty about the timing of fertility and the anticipation that they will not have children have a surprisingly similar effect on transition risks. Hypothesis 4, namely that fertility orientations have a stronger influence on the transition to coresidential partnership, was generally supported across the different models. As far as the factors of uncertainty about childbearing, the length of time to pass before anticipated childbearing and the anticipation 
among respondents that they will not have children are concerned, the reduction in transition risks is greater in models (c) and (d) than in models (a) and (b).

It is worthwhile taking a closer look at the gender differences in the strength and significance of the influences. Influences are generally greater among men, while the significance is also consistently high. Gender differences are even more pronounced with respect to the transition to a romantic partnership, with the expected timing of childbearing having hardly any influence among women. Both findings are in line with the argument put forward by Ehrhardt and Kohli (2011). They assume that men fear losing their investment in children in the event of separation from the mother as the latter is most likely to be in charge of childrearing following a separation. The will to establish a solid partnership is therefore likely to be greater among men than women. Furthermore, men depend more than women on finding a partner if they definitely want to become a parent; women, on the other hand, have a number of other possible routes to parenthood open to them, e.g. through sperm donation (Gray et al. 2013; Kuhnt/Buhr 2016). The fact that uncertainty as regards childbearing and the anticipation of not having children have similar effects among men but not among women suggests that uncertainty has a different meaning and therefore different consequences in the two gender groups (suggested also by findings of Kuhnt/Buhr 2016; Miettinen/Paajanen 2005). Among men, uncertainty is regarded more as being equivalent to not actively pursuing fertility plans. Uncertainty among women, on the other hand, could be due to other reasons, for example only wanting to have children with the "right partner" or ensuring that the woman herself or the couple has a secure financial background.

\section{Discussion}

Using data from the German Family Panel (pairfam) and Cox proportional hazard regression models, I have empirically demonstrated for the first time that the anticipation of fertility in general, uncertainty about fertility prospects as well as the estimated timing of fertility (reported as being "realistic" by respondents, collectively referred to as fertility orientations) influence partnership transition risks. These risks are greater among men and women who expect to have children, particularly if they anticipate childbearing in the near future. The influences were stronger among men and for the transition to a coresidential partnership. This is consistent with assumptions made in earlier research, which highlighted that coresidence is often considered a prerequisite for childbearing (e.g. Rijken/Thomson 2011; Spéder/Kapitány 2009; Berrington 2001) and that men are at a higher risk of losing an investment in a child in the event of separation from a partner (Huinink/Kohli 2014). Furthermore, women have other ways in which they can become a parent, while men depend heavily on finding a partner (Gray et al. 2013; Kuhnt/Buhr 2016). Uncertainty also affects partnership formation differently in both gender groups (as suggested in previous research by Berrington 2004; Kuhnt/Buhr 2016; Miettinen/ Paajanen 2005). 
This paper contributes to existing knowledge by helping to clarify the link between the life course dimensions of partnership and fertility in terms of the influences that fertility orientations have on partnership formation in Germany. This evidence can be useful in conceptualizing in a more comprehensive manner the role played by fertility within life course research (suggested by Huinink/Kohli 2014), which considers interdependencies between different life course dimensions. Results also suggest that the link between fertility orientations and partnership formation can be more or less close, and is likely to vary depending on the stage within the partnership formation process and between respondent groups, as demonstrated by the differences between men and women in this research. This supports theoretical notions from life course theory (e.g. Bernardi et al. 2019; Huinink/Feldhaus 2009; Mayer 2019), theories on individualisation (e.g. Beck 1992) and value changes (Inglehart/Welzel 2005; Lesthaeghe 2010, 2011; Van de Kaa 2001) as well as differentiation of private life (e.g. Meyer 1992, 2014). All theories mentioned in the last sentence suggest that life course domains are increasingly formally independent of each other and that individuals can and need to choose how (best) to connect them in order to maximise their own welfare. Establishing which life course domains and life events are more or less strongly linked in a specific setting and respondent group is thus a matter of empirical research rather than theory, while more detailed theoretical work is needed to explain these links (Huinink/Feldhaus 2009).

The findings have therefore illustrated the complex and intertwined nature of different life course areas (partnership and fertility) as well as life course phases; simple, unidirectional models of the influences that early life course phases have on later life course phases might be too simplistic (Elder 1985; Elder et al. 2003; Levy 1977; Mayer 1990, 2004, 2009). As a result, this research complements earlier research, such as that by Born (2001), Carroll et al. (2007), Krüger (2014), Wagner et al. (2019a/b) and Willoughby (2014) on different topics, all of which show that biographical orientations over the longer term influence both the present and the shorter term in many different dimensions of the life course.

This paper has several limitations, which is why further research is required. The respondents in my analysis were young, a fact attributable to many older respondents having already had children and/or a partner, thereby excluding them from the analysis. This was generally a positive factor and was necessary for the analysis and the research question since partnership formation largely takes place in younger years. This meant that the target group was generally well suited to answer the research question at hand. Further research on the influence of fertility orientations, using larger sample of older respondents (in addition to the work already done by Wagner et al. 2019a), could add extra value and test the assumptions of this research for older respondents, for whom the ticking of the biological clock might be more influential.

Due to the specific characteristics of the German context (e.g. strong link between marriage and childbearing, high proportion of both men and women remaining childless, partnerships adopting a more traditional course following the birth of children, strong two-child norm), the results are not easily transferable 
to other countries. Further research is needed to understand whether and how the two dimensions are linked in other countries. The gender differences could only partly be explained. In particular, the different role that uncertainty about anticipated childbearing among men and women plays in terms of partnership formation requires further research. To better understand the importance of fertility orientations within multidimensional life courses, it would also be useful to analyse the influences of fertility orientations on events in other life course dimensions, e.g. education or work.

I argue that reverse causality is not a major problem within my analysis, as fertility orientations were measured before partnership events took place and were reported. However, individuals might take the decision to enter a romantic or coresidential partnership before the actual event occurs. This is more likely to be the case for coresidential partnerships because most partners who intend to cohabit need to find a suitable housing option before they can put their plan into practice. Therefore, individuals might already plan on starting a coresidential partnership (long) before the actual event takes place and before fertility orientations are measured. The plan/ intention could thus influence the reported anticipations of future fertility. However, I argue that a plan or an intention to enter a romantic or coresidential partnership is not equivalent to actually doing so; a considerable amount of uncertainty remains, therefore, as to whether the plan will prove successful. Consequently, it is likely that intentions to form a romantic or coresidential partnership will, at most, have a very limited influence on fertility orientations.

Additionally, I am unable to distinguish between partnership transitions which are just trials or experiments, and those partnership transitions which are more relevant for the individuals (see Lois 2012 for an overview of types of early-stage partnerships). Prior research, however, suggests that trial partnerships are not very common among young people in Germany, or at least not commonly reported within surveys like the German Family Panel (Hoppmann/Zimmermann 2018). Therefore, these partnerships are likely to represent only a minority of partnerships and it can be comfortably assumed that this limitation does not seriously influence the results.

The principle of linked lives (Elder 1985) suggests that both (potential) partners' fertility orientations influence partnership transition risks. This was not a focus of the current research because this perspective would only allow an analysis of the risk of transitioning to coresidential partnership or marriage, due to the non-availability of attitudinal data for partners before the start of the partnership. Furthermore, not all partners filled out the questionnaire for a partner, leading to significant reductions in sample size. However, analysing the influence that both partners' fertility orientations have on the risk of transitioning to coresidential partnership or marriage for a reduced sample would be possible based on data from the German Family Panel. It would be worthwhile analysing these effects in future research in order to validate the findings of this study.

Based on life course and individualisation theory as well as theory on the differentiation of private lives, I argued that fertility orientations and partnership transition risks are likely to be independent of each other for the most part. I therefore do not assume that they are determined by an underlying attitude towards 
family formation. This latter view is nevertheless suggested by the works of Filandri et al. (2016), Hakim (2000), Rackin (2013) and Testa (2007), however. Because of the contradicting theoretical positions, it would still be worthwhile to test whether a common determining factor, such as a more abstract preference for familial relationships, could be established. It is also possible that both perspectives are true - that there is indeed a common determining factor as well as some independence and mutual influences of the phenomena. However, to my knowledge, there is no data set available which includes a more abstract variable on the importance of family relationships, which could serve as an explaining variable for testing the hypothesis about a common determining factor. Nor is there any methodology available which can identify such abstract concepts based on more specific information from attitudinal and longitudinal data. Therefore, this question has to remain open for now, to be potentially answered in future research.

\section{References}

Ajzen, Icek 1991: The Theory of Planned Behavior. In: Organizational Behavior and Human Decision Processes 50,2: 179-211. https://doi.org/10.1016/0749-5978(91)90020-T

Andersen, Signe Hald; Özcan, Berkay 2021: The Effects of Unemployment on Fertility. In: Advances in Life Course Research (Journal Pre-proof). https://doi.org/10.1016/j.alcr.2020.100401

Aries, Philippe 1980: Two Successive Motivations for the Declining Birth Rate in the West. In: Population and Development Review 6,4: 645-650. https://doi.org/10.2307/1972930

Bachrach, Christine A.; Morgan, S. Philip 2013: A Cognitive-Social Model of Fertility Intentions. In: Population and Development Review 39,3: 459-485. https://doi.org/10.1111/j.1728-4457.2013.00612.x

Barrett, Geraldine; Smith, Sarah C.; Wellings, Kaye 2004: Conceptualisation, Development, and Evaluation of a Measure of Unplanned Pregnancy. In: Journal of Epidemiology and Community Health 58,5: 426-433. https://doi.org/10.1136/jech.2003.014787

Beck, Ulrich 1992: Risk Society: Towards a New Modernity. London: Sage Publications.

Becker, Gary S. 1981: A Treatise on the Family. Cambridge, Massachusetts: Harvard University Press.

Beckmann, Jürgen; Heckhausen, Heinz 2018: Motivation as a Function of Expectancy and Incentive. In: Heckhausen, Jutta; Heckhausen, Heinz (Eds.): Motivation and Action. New York: Springer: 163-220. https://doi.org/10.1007/978-3-319-65094-4_5

Bernardi, Laura; Huinink, Johannes; Settersten, Richard A. Jr. 2019: The Life Course Cube: A Tool for Studying Lives. In: Advances in Life Course Research 41. https://doi.org/10.1016/j.alcr.2018.11.004

Bernardi, Laura; Mynarska, Monika; Rossier, Clémentine 2015: Uncertain, Changing and Situated Fertility Intentions. A Qualitative Analysis. In: Philipov, Dimiter; Liefbroer, Aart C.; Klobas, Jane E. (Eds.): Reproductive Decision-Making in a Macro-Micro Perspective. Dordrecht: Springer: 113-139. https://doi.org/10.1007/978-94-017-9401-5 5 
Berrington, Ann 2001: Entry Into Parenthood and the Outcome of Cohabiting Partnerships in Britain. In: Journal of Marriage and Family 63,1: 80-96. https://doi.org/10.1111/j.1741-3737.2001.00080.x

Berrington, Ann 2004: Perpetual Postponers? Women's, Men's and Couple's Fertility Intentions and Subsequent Fertility Behaviour. In: Population Trends 117: 9-19.

Berrington, Ann; Pattaro, Serena 2014: Educational Differences in Fertility Desires, Intentions and Behaviour: A Life Course Perspective. In: Advances in Life Course Research 21: 10-27. https://doi.org/10.1016/j.alcr.2013.12.003

Born, Claudia 2001: Modernisierungsgap und Wandel. Angleichung geschlechtsspezifischer Lebensführungen? In: Born, Claudia; Krüger, Helga (Eds.): Individualisierung und Verflechtung. Geschlecht und Generation im Lebenslaufregime. Weinheim/München: Juventa: 29-54.

Brown, Susan L.; Bulanda, Jennifer Roebuck; Lee, Gary R. 2012: Transitions Into and Out of Cohabitation in Later Life. In: Journal of Marriage and Family 74,4: 774-793. https://doi.org/10.1111/j.1741-3737.2012.00994.x

Brüderl, Josef 2010: Kausalanalyse mit Paneldaten. In: Wolf, Christof; Best, Henning (Eds.): Handbuch der sozialwissenschaftlichen Datenanalyse. Wiesbaden: VS Verlag für Sozialwissenschaften: 963-994. https://doi.org/10.1007/978-3-531-92038-2_36

Brüderl, Josef et al. 2019: The German Family Panel (pairfam). GESIS Data Archive, Cologne. ZA5678 Data file Version 10.0.0. https://doi.org/10.4232/pairfam.5678.10.0.0

Buhr, Petra; Huinink, Johannes 2014: Fertility Analysis from a Life Course Perspective. In: Advances in Life Course Research 21: 1-9. https://doi.org/10.1016/j.alcr.2014.04.001

Carroll, Jason S. et al. 2007: So Close, Yet So Far Away: The Impact of Varying Marital Horizons on Emerging Adulthood. In: Journal of Adolescent Research 22,3: 219-247. https://doi.org/10.1177/0743558407299697

Cherlin, Andrew J. 2004: The Deinstitutionalization of American Marriage. In: Journal of Marriage and Family 66,4: 848-861. https://doi.org/10.1111/j.0022-2445.2004.00058.x

Clark, William A. V.; Onaka, Jun L. 1983: Life Cycle and Housing Adjustment as Explanations of Residential Mobility. In: Urban Studies 20,1: 47-57. https://doi.org/10.1080/713703176

Comolli, Chiara L. 2021: Resources, aspirations and first births during the great recession. Advances in Life Course Research (Journal Pre-proof). https://doi.org/10.1016/j.alcr.2021.100405

Coontz, Stephanie 2004: The World Historical Transformation of Marriage. In: Journal of Marriage and Family 66,4: 974-979. https://doi.org/10.1111/j.0022-2445.2004.00067.x

Cox, David R. 1972: Regression Models and Life Tables. In: Journal of the Royal Statistical Society B 34,2: 187-200. https://doi.org/10.1111/j.2517-6161.1972.tb00899.x

Davis, Fred D.; Warshaw, Paul R. 1992: What Do Intention Scales Measure? In: Journal of General Psychology 119,4: 391-407. https://doi.org/10.1080/00221309.1992.9921181

Duncan, Simon; Phillips, Miranda 2011: People Who Live Apart Together (LATs): New Family Form or Just a Stage? In: International Review of Sociology 21,3: 513-532. https://doi.org/10.1080/03906701.2011.625660

Ehrhardt, Jens; Kohli, Martin 2011: Individualisation and Fertility. In: Historical Social Research 36,2: 35-64. https://doi.org/10.12759/hsr.36.2011.2.35-64

Elder, Glen H. 1985: Preface. In: Elder, Glen H. (Ed.): Life Course Dynamics: Trajectories and Transitions, 1968-1980. Ithaca: Cornell University Press: 15-19. 
Elder, Glen H.; Johnson, Monica Kirkpatrick; Crosnoe, Robert 2003: The Emergence and Development of Life Course Theory. In: Mortimer, Jeylan T.; Shanahan, Michael J. (Eds.): Handbook of the Life Course. New York: Kluwer Academic/Plenum Publishers: 3-19.

Eurostat 2018: Are More Babies Born Inside or Outside Marriage? In: Eurostat News 16.04.2018 [https://ec.europa.eu/eurostat/web/products-eurostat-news/-/DDN20180416-1, 22.01.2021].

Filandri, Marianna et al. 2016: Family Formation Strategies among the Youth. In: Style Working Papers WP8,5 [URL: https://www.style-research.eu/wp-content/ uploads/2017/04/D-8.5-Family-formation-strategies-among-the-youth.pdf, 28.08.2020].

Gray, Edith; Evans, Ann; Reimondos, Anna 2013: Childbearing Desires of Childless Men and Women: When are Goals Adjusted? In: Advances in Life Course Research 18,2: 141-149. https://doi.org/10.1016/j.alcr.2012.09.003

Hakim, Catherine 2000: Work-Lifestyle Choices in the 21 ${ }^{\text {st }}$ Century. Preference Theory. Oxford: Oxford University Press.

Heckhausen, Jutta; Heckhausen, Heinz 2010: Motivation und Handeln: Einführung und Überblick. In: Heckhausen, Jutta; Heckhausen, Heinz (Eds.): Motivation und Handeln. $4^{\text {th }}$ edition. Berlin/Heidelberg: Springer: 1-14. https://doi.org/10.1007/978-3-642-12693-2_1

Heckhausen, Jutta; Heckhausen, Heinz 2018: Introduction and Overview. In: Heckhausen, Jutta; Heckhausen, Heinz (Eds.): Motivation and Action. $5^{\text {th }}$ edition. Cham: Springer International Publishing: 1-14. https://doi.org/10.1007/978-3-319-65094-4_1

Heintz-Martin, Valerie; Zabel, Cordula 2019: The Stability of Partnerships across the Transition from Education to Employment. In: Journal of Youth Studies 22,8: 10171034. https://doi.org/10.1080/13676261.2018.1562164

Hiekel, Nicole; Liefbroer, Aart C.; Poortman, Anne-Rigt 2014: Understanding Diversity in the Meaning of Cohabitation Across Europe. In: European Journal of Population 30,4: 391-410. https://doi.org/10.1007/s10680-014-9321-1

Hiekel, Nicole; Liefbroer, Aart C.; Poortman, Anne-Rigt 2015: Marriage and Separation Risks among German Cohabiters: Differences between Types of Cohabiter. In: Population Studies. A Journal of Demography 69,2: 237-251. https://doi.org/10.1080/00324728.2015.1037334

Hoppmann, Isabella; Zimmermann, Okka 2018: "Living Apart Together" in der Jugend Nur eine Vorstufe zur Kohabitation? In: Diskurs Kindheits- und Jugendforschung 13,1: 69-86. https://doi.org/10.3224/diskurs.v13i1.06

Huinink, Johannes; Feldhaus, Michael 2009: Family Research from the Life Course Perspective. In: International Sociology 24,3: 299-324. https://doi.org/10.1177/0268580909102910

Huinink, Johannes; Kohli, Martin 2014: A Life-Course Approach to Fertility. In: Demographic Research 30,45: 1293-1326. https://doi.org/10.4054/DemRes.2014.30.45

Huinink, Johannes et al. 2011: Panel Analysis of Intimate Relationships and Family Dynamics (pairfam): Conceptual Framework and Design. In: Zeitschrift für Familienforschung 23,1: 77-101.

Inglehart, Ronald; Welzel, Christian 2005: Modernization, Cultural Change, and Democracy: The Human Development Sequence. Cambridge: Cambridge University Press. 
Johnson-Hanks, Jennifer A. et al. 2011: Understanding Family Change and Variation. Toward a Theory of Conjunctural Action. Understanding Population Trends and Processes series 5. Dordrecht: Springer.

Keddi, Barbara 2006: Liebe als biografisches Projekt. In: Engelen, Eva-Maria; RöttgerRössler, Birgitt (Eds.): „Tell me about love“ - Kultur und Natur der Liebe. Paderborn: Metis: 143-164.

Keddi, Barbara 2010: Junge Frauen. In: Becker, Ruth; Kortendiek, Beate (Eds.): Handbuch Frauen- und Geschlechterforschung. Wiesbaden: VS Verlag für Sozialwissenschaften: 436-441. https://doi.org/10.1007/978-3-531-92041-2_52

Kohli, Martin 1986: The World We Forgot: A Historical Review of the Life Course. In: Marshall, Victor W. (Ed.): Later Life. The Social Psychology of Aging. Beverly Hills, Calif: Sage: 271-303.

Kohli, Martin 2007: The Institutionalization of the Life Course: Looking Back to Look Ahead. In: Research in Human Development 4,3-4: 235-271. https://doi.org/10.1080/15427600701663122

Konietzka, Dirk; Kreyenfeld, Michaela 2017: Von der alternativen zur prekären Familienform? Der Wandel des Zusammenhangs von Bildung und nichtehelichen Familienformen in Deutschland. In: Swiss Journal of Sociology 43,3: 611-637. https://doi.org/10.1515/sjs-2017-0030

Konietzka Dirk; Zimmermann, Okka 2020: Die Familie in der Gegenwart. In: Ecarius, Jutta; Schierbaum, Anja (Eds.): Handbuch Familie. Wiesbaden: Springer VS: Online First. https://doi.org/10.1007/978-3-658-19416-1_9-1

Kopp et al. 2010: Verliebt, verlobt, verheiratet. Institutionalisierungsprozesse in Partnerschaften. Wiesbaden: VS Verlag für Sozialwissenschaften. https://doi.org/10.1007/978-3-531-92304-8

Kreyenfeld, Michaela; Konietzka, Dirk 2017: Childlessness in East and West Germany: Long-Term Trends and Social Disparities. In: Kreyenfeld, Michaela; Konietzka, Dirk (Eds.): Childlessness in Europe: Contexts, Causes, and Consequences. Demographic Research Monographs book series of the Max Planck Institute for Demographic Research. Cham: Springer: 97-114. https://doi.org/10.1007/978-3-319-44667-7_5

Krüger, Judith 2014: Erwerbsverläufe von FacharbeiterInnen. Untersuchung eines Automobilunternehmens unter besonderer Berücksichtigung der Vereinbarkeit von Beruf und Privatleben. AutoUni series of the Volkswagen AG 57. Berlin: Logos.

Kuhnt, Anne-Kristin; Buhr, Petra 2016: Biographical Risks and their Impact on Uncertainty in Fertility Expectations. A Gender-specific Study Based on the German Family Panel. Duisburger Beiträge zur soziologischen Forschung 2016,3. https://doi.org/10.6104/DBsF-2016-03

Kuhnt, Anne-Kristin; Trappe, Heike 2016: Channels of Social Influence on the Realization of Short-Term Fertility Intentions in Germany. In: Advances in Life Course Research 27: 16-29. https://doi.org/10.1016/j.alcr.2015.10.002

Kuhnt, Anne-Kristin; Minkus, Lara; Buhr, Petra 2020: Uncertainty in Fertility Intentions from a Life Course Perspective: Which Life Course Markers Matter? In: Journal of Family Research (Early View). https://doi.org/10.20377/jfr-426

Lappegård, Trude; Klüsener, Sebastian; Vignoli, Daniele 2017: Why are Marriage and Family Formation Increasingly Disconnected across Europe? A Multilevel Perspective on Existing Theories. In: Population, Space and Place 24,2: e2088.

https://doi.org/10.1002/psp.2088 
Lauer, Sean; Yodanis, Carrie 2010: The Deinstitutionalization of Marriage Revisited: A New Institutional Approach to Marriage. In: Journal of Family Theory \& Review 2,1: 58-72. https://doi.org/10.1111/j.1756-2589.2010.00039.x

Lesthaeghe, Ron 2010: The Unfolding Story of the Second Demographic Transition. In: Population and Development Review 36,2: 211-251. https://doi.org/10.1111/j.1728-4457.2010.00328.x

Lesthaeghe, Ron 2011: The "Second Demographic Transition": A Conceptual Map for the Understanding of Late Modern Demographic Developments in Fertility and Family Formation. In: Historical Social Research 36,2: 179-218. https://doi.org/10.12759/hsr.36.2011.2.179-218

Levin, Irene; Trost, Jan 1999: Living Apart Together. In: Community, Work \& Family 2,3: 279-294. https://doi.org/10.1080/13668809908412186

Levy, René 1977: Der Lebenslauf als Statusbiographie. Die weibliche Normalbiographie in makrosoziologischer Perspektive. Stuttgart: Ferdinand Enke Verlag.

Liefbroer, Aart C.; Poortman, Anne-Rigt; Seltzer, Judith 2015: Why Do Intimate Partners Live Apart? Evidence on LAT Relationships across Europe. In: Demographic Research 32,8: 251-286. https://doi.org/10.4054/DemRes.2015.32.8

Lois, Nadia 2012: „Living Apart Together": Sechs Typen einer heterogenen Lebensform In: Journal of Family Research 24,3: 247-268. https://doi.org/10.20377/jfr-172

Macmillan, Ross; Copher, Ronda 2005: Families in the Life Course: Interdependency of Roles, Role Configurations, and Pathways. In: Journal of Marriage and Family 67,4: 858-879. https://doi.org/10.1111/j.1741-3737.2005.00180.x

Mayer, Karl U. 1990: Lebensläufe und sozialer Wandel. In: Kölner Zeitschrift für Soziologie und Sozialpsychologie, Sonderheft 31: 7-21.

Mayer, Karl U. 2004: Whose Lives? How History, Societies, and Institutions Define and Shape Life Courses. In: Research in Human Development 1,3: 161-187. https://doi.org/10.1207/s15427617rhd0103_3

Mayer, Karl U. 2009: New Directions in Life Course Research. In: Annual Review of Sociology 35,1: 413-433. https://doi.org/10.1146/annurev.soc.34.040507.134619

Mayer, Karl U. 2019: On Heuristics, Theoretical Foundations, Accounting Schemes and Theories. In: Advances in Life Course Research 41,1: 1-4. https://doi.org/10.1016/j.alcr.2019.04.007

Meyer, Thomas 1992: Modernisierung der Privatheit. Differenzierungs- und Individualisierungsprozesse des familialen Zusammenlebens. Studien zur Sozialwissenschaft 110. Opladen: Westdeutscher Verlag. https://doi.org/10.1007/978-3-663-01679-3

Meyer, Thomas 2014: Der Wandel der Familie und anderer privater Lebensformen. In: Geißler, Rainer: Die Sozialstruktur Deutschlands. 7th edition. Wiesbaden: Springer VS.

Michielin, Francesca; Mulder, Clara H. 2008: Family Events and the Residential Mobility of Couples. In: Environment and Planning A: Economy and Space 40,11: 2770-2790. https://doi.org/10.1068/a39374

Miettinen, Anneli; Paajanen, Pirjo 2005: Yes, No, Maybe: Fertility Intentions and Reasons Behind Them among Childless Finnish Men and Women. In: Finnish Yearbook of Population Research 41: 165-184. https://doi.org/10.23979/fypr.45020

Miller, Warren 1994: Childbearing Motivation, Desires, and Intentions: A Theoretical Framework. In: Genetic Social and General Psychology Monographs 120,2: 223-258. 
Morgan, S. Philip 1981: Intention and Uncertainty at Later Stages of Childbearing: The United States, 1965-1970. In: Demography 18,3: 267-285. https://doi.org/10.2307/2060997

Morgan, S. Philip 1982: Parity-specific Fertility Intentions and Uncertainty: The United States, 1970 to 1976. In: Demography 19,3: 315-334. https://doi.org/10.2307/2060974

Nave-Herz, Rosemarie 2015: Familie heute: Wandel der Familienstrukturen und Folgen für die Erziehung. $6^{\text {th }}$ editon. Darmstadt: WBG.

Ní Bhrolcháin, Márie; Beaujouan, Éva 2011: Uncertainty in Fertility Intentions in Britain, 1979-2007. In: Vienna Yearbook of Population Research 9,1: 99-129. https://doi. org/10.1553/populationyearbook2011s99

Ní Bhrolcháin, Márie; Beaujouan, Éva 2015: How Real are Reproductive Goals? Uncertainty and the Construction of Fertility Preferences. ESRC Centre for Population Change Working Paper 73. https://doi.org/10.13140/RG.2.1.3495.6884

Ní Bhrolcháin, Máire; Beaujouan, Éva 2019: Do People Have Reproductive Goals? Constructive Preferences and the Discovery of Desired Family Size. In: Schoen, Robert (Ed.): Analytical Family Demography. Cham: Springer International Publishing: 27-56. https://doi.org/10.1007/978-3-319-93227-9_3

Ní Bhrolcháin, Márie; Beaujouan, Éva; Berrington, Ann 2010: Stability and Change in Fertility Intentions in Britain, 1991-2007. In: Population Trends 141: 13-35. https://doi.org/10.1057/pt.2010.19

Ostner, Ilona 2001: Cohabitation in Germany - Rules, Reality and Public Discourses. In: International Journal of Law, Policy and the Family 15,1: 88-101. https://doi.org/10.1093/lawfam/15.1.88

Philipov, Dimiter; Bernardi, Laura 2011: Concepts and Operationalisation of Reproductive Decisions. Implementation in Austria, Germany and Switzerland. In: Comparative Population Studies 36,2-3: 495-530. https://doi.org/10.12765/CPoS-2011-14

Raab, Marcel 2017: Childhood Family Structure and Early Family Formation in East and West Germany. In: Journal of Marriage and Family 79,1: 110-130. https://doi.org/10.1111/jomf.12333

Rackin, Heather M. 2013: Where Should Babies Come From? Measuring Schemas of Fertility and Family Formation Using Novel Theory and Methods. Duke University: Dissertation. [https://dukespace.lib.duke.edu/dspace/bitstream/handle/10161/8040/ Rackin_duke_0066D_12052.pdf?sequence=1, 28.08.2020].

Rackin, Heather M.; Bachrach, Christine A. 2016: Assessing the Predictive Value of Fertility Expectations Through a Social-Cognitive Model. In: Population Research and Policy Review 35,4: 527-551. https://doi.org/10.1007/s11113-016-9395-z

Rijken, Arieke J.; Thomson, Elizabeth 2011: Partners' Relationship Quality and Childbearing. In: Social Science Research 40,2: 485-497. https://doi.org/10.1016/j.ssresearch.2010.10.001

Ruckdeschel, Kerstin et al. 2018: Unequal Neighbours? A French-German Comparison of Family Size Intentions. In: Comparative Population Studies 43: 187-210. https://doi.org/10.12765/CPoS-2018-12

Santelli, John S. et al. 2009: Toward a Multidimensional Measure of Pregnancy Intentions: Evidence from the United States. In: Studies in Family Planning 40,2: 87-100. https:// doi.org/10.1111/j.1728-4465.2009.00192.x

Schaeffer, Nora Cate; Thomson, Elizabeth 1992: The Discovery of Grounded Uncertainty: Developing Standardized Questions about Strength of Fertility Motivation. In: Sociological Methodology 22: 37-82. https://doi.org/10.2307/270992 
Schmitt, Christian 2021: The Impact of Economic Uncertainty, Precarious Employment, and Risk Attitudes on the Transition to Parenthood. In: Advances in Life Course Research: Online First. https://doi.org/10.1016/j.alcr.2021.100402

Schoenfeld, David 1982: Partial Residuals for the Proportional Hazards Regression Model. In: Biometrika 69,1: 239-241. https://doi.org/10.2307/2335876

Schröder, Jette; Schmiedeberg, Claudia; Brüderl, Josef 2016: Beyond the Two-Child Family: Factors Affecting Second and Third Birth Rates in West Germany. In: Zeitschrift für Familienforschung 28,1: 3-18. https://doi.org/10.3224/zff.v28i1.22918

Settersten, Richard A.; Gannon, Lynn 2005: Structure, Agency, and the Space Between: On the Challenges and Contradictions of a Blended View of the Life Course. In: Advances in Life Course Research 10: 35-55. https://doi.org/10.1016/S1040-2608(05)10001-X

Smith, Imogene et al. 2020: When Men Choose to be Childless: An Interpretative Phenomenological Analysis. In: Journal of Social and Personal Relationships 37,1: 325-344. https://doi.org/10.1177/0265407519864444

Sobotka, Tomáš 2009: Sub-Replacement Fertility Intentions in Austria. In: European Journal of Population 25,4: 387-412. https://doi.org/10.1007/s10680-009-9183-0

Spéder, Zsolt; Kapitány, Balázs 2009: How are Time-Dependent Childbearing Intentions Realized? Realization, Postponement, Abandonment, Bringing Forward. In: European Journal of Population 25,4: 503-523. https://doi.org/10.1007/s10680-009-9189-7

Statista 2020: Share of Children Born Outside of Marriage among All Live Births in Germany from 1970 to 2019 [https://www.statista.com/statistics/1094231/childrenborn-outside-of-marriage-germany/, 22.01.2021].

Testa, Maria R. 2007: Childbearing Preferences and Family Issues in Europe: Evidence from the Eurobarometer 2006 Survey. In: Vienna Yearbook of Population Research 5: 357-379. https://doi.org/10.1553/populationyearbook2007s357

Thönnissen, Carolin et al. 2018: Pairfam Scales and Instruments Manual. The German Family Panel (pairfam). GESIS Data Archive, Cologne. ZA5678 Data file Version 10.0.0. https://doi.org/10.4232/pairfam.5678.10.0.0

Thornton, Arland; Axinn, William G.; Xie, Yu 2007: Marriage and Cohabitation. Population and Development Series. Chicago: University of Chicago Press.

Van de Kaa, Dirk. J. 2001: Postmodern Fertility Preferences: From Changing Value Orientation to New Behavior. In: Population and Development Review 27: 290-331.

Verweij, Renske et al. 2020: Three Facets of Planning and Postponement of Parenthood in the Netherlands. In: Demographic Research 43,23: 659-672. https://doi.org/10.4054/DemRes.2020.43.23

Vidal, Sergi; Huinink, Johannes; Feldhaus, Michael 2017: Fertility Intentions and Residential Relocations. In: Demography 54,4: 1305-1330. https://doi.org/10.1007/s13524-017-0592-0

Wagner, Michael; Huinink, Johannes; Liefbroer, Aart C. 2019a: Running Out of Time? Understanding the Consequences of the Biological Clock for the Dynamics of Fertility Intentions and Union Formation. In: Demographic Research 40,1: 1-26. https://doi.org/10.4054/DemRes.2019.40.1

Wagner et al. 2019b: The Transition from Living Apart Together to a Coresidential Partnership. In: Advances in Life Course Research 39: 77-86. https://doi.org/10.1016/j.alcr.2018.12.002

Walker, Laquitta M. 2016: Deinstitutionalization of Marriage. In: Shehan, Constance L. (Ed.): The Wiley Blackwell Encyclopedia of Family Studies. New York: John Wiley \& Sons: $1-3$ 
Willoughby, Brian J. 2014: Using Marital Attitudes in Late Adolescence to Predict Later Union Transitions. In: Youth \& Society 46,3: 425-440. https://doi.org/10.1177/0044118X12436700

Wilson, Chris; Oeppen, Jim 2003: On Reification in Demography. In: Fleischhacker, Jochen; de Gans, Hans; Burch, Thomas (Eds.): Population, Projections and Politics. Critical and Historical Essays on Early Twentieth Century Population Forecasting. Amsterdam: Rozenberg: 113-129.

Zaidi, Batool; Morgan, S. Philip 2017: The Second Demographic Transition Theory: A Review and Appraisal. In: Annual Review of Sociology 43: 473-492. https://doi.org/10.1146/annurev-soc-060116-053442

Zimmermann, Okka 2019: Der ,kritische‘ und ,neoliberale' Vereinbarkeitsdiskurs in der Alltagskommunikation berufstätiger Mütter. In: GENDER - Zeitschrift für Geschlecht, Kultur und Gesellschaft 11,2: 121-137. https://doi.org/10.3224/gender.v11i2.09

Dr. Okka Zimmermann ( $₫)$. Technische Universität Braunschweig, Institute of Sociology. Braunschweig, Germany. E-mail: o.zimmermann@tu-braunschweig.de URL: https://www.tu-braunschweig.de/ses/team/zimmermann 


\section{Appendix}

Tab. A1: Results of Cox proportional hazard regression models for single destinations (Cox 1972), sensitivity analyses with a continuous independent variable

\begin{tabular}{|c|c|c|c|c|}
\hline \multirow[t]{6}{*}{$\begin{array}{l}\text { Influences on transition } \\
\text { risks to ... }\end{array}$} & \multicolumn{2}{|c|}{$\begin{array}{l}\text {.... a romantic partnership } \\
\text { (data-set } \mathrm{A})\end{array}$} & \multicolumn{2}{|c|}{$\begin{array}{c}\ldots \text { a coresidential partnership } \\
\text { (data-set B) }\end{array}$} \\
\hline & $\begin{array}{l}\text { Women } \\
\text { (a) }\end{array}$ & $\begin{array}{l}\text { Men } \\
\text { (b) }\end{array}$ & $\begin{array}{l}\text { Women } \\
\text { (c) }\end{array}$ & $\begin{array}{l}\text { Men } \\
\text { (d) }\end{array}$ \\
\hline & Obs. 2,453 & Obs. 3,497 & Obs. 5,097 & Obs. 5,991 \\
\hline & Resp. 1,026 & Resp. 1,354 & Resp. 1,544 & Resp. 1,770 \\
\hline & Trans. 993 & Trans. 1,188 & Trans. 791 & Trans. 681 \\
\hline & Prob $>\mathrm{Chi}^{2} .019$ & Prob $>\mathrm{Chi}^{2} .001$ & Prob $>\mathrm{Chi}^{2} .000$ & Prob $>\mathrm{Chi}^{2} .000$ \\
\hline \multicolumn{5}{|l|}{ Anticipated years until birth } \\
\hline of the $1^{\text {st }}$ child (cont.) & $.964^{*}$ & $.939 * * *$ & $.849 * * *$ & $.799 * * *$ \\
\hline \multicolumn{5}{|c|}{ Migration status [reference: no migration background] } \\
\hline $2^{\text {nd }}$ generation migrant & 1.214 & .995 & .953 & $.691^{*}$ \\
\hline \multicolumn{5}{|l|}{ Region [reference: West] } \\
\hline East & 1.127 & 1.094 & 1.160 & 1.011 \\
\hline \multicolumn{5}{|c|}{ Size of community [reference: $5,000-<20,000$ ] } \\
\hline $500,000+$ & .826 & 1.187 & .962 & .969 \\
\hline $100,000-<500,000$ & 1.054 & 1.100 & 1.060 & 1.096 \\
\hline $50,000-<100,000$ & .913 & 1.207 & 1.002 & .918 \\
\hline $20,000-<50,000$ & $.769^{*}$ & 1.095 & 1.134 & 1.143 \\
\hline$<5,000$ & 1.004 & .967 & 1.137 & 1.035 \\
\hline Good health & 1.020 & 1.020 & .986 & 1.064 \\
\hline \multicolumn{5}{|c|}{ Activity status [reference: in education] } \\
\hline Regular full-time employment & 1.077 & 1.102 & $1.574 * * *$ & $1.545^{* * *}$ \\
\hline Other employment ${ }^{1}$ & 1.028 & .995 & 1.309 & $1.395^{*}$ \\
\hline Not employed ${ }^{2}$ & .763 & $.717^{*}$ & 1.167 & 1.133 \\
\hline Age & $.962^{* *}$ & $.964 * * *$ & .981 & .997 \\
\hline
\end{tabular}

1 Including self-employment, part-time and marginal employment, internships, services (i.e. military or civilian service), irregular employment.

2 Including maternal or paternal leave, retirement, disability, joblessness. 
Tab. A1: Continuation

\begin{tabular}{|c|c|c|c|c|}
\hline \multirow[t]{7}{*}{$\begin{array}{l}\text { Influences on transition } \\
\text { risks to ... }\end{array}$} & \multicolumn{2}{|c|}{$\begin{array}{c}\ldots \text { a romantic partnership } \\
\text { (data-set } A)\end{array}$} & \multicolumn{2}{|c|}{$\begin{array}{c}\text {... a coresidential partnership } \\
\text { (data-set B) }\end{array}$} \\
\hline & Women & Men & Women & Men \\
\hline & (a) & (b) & (c) & (d) \\
\hline & Obs. 2,453 & Obs. 3,497 & Obs. 5,097 & Obs. 5,991 \\
\hline & Resp. 1,026 & Resp. 1,354 & Resp. 1,544 & Resp. 1,770 \\
\hline & Trans. 993 & Trans. 1,188 & Trans. 791 & Trans. 681 \\
\hline & Prob $>\mathrm{Chi}^{2} .019$ & Prob $>\mathrm{Chi}^{2} .001$ & Prob $>\mathrm{Chi}^{2} .000$ & Prob $>\mathrm{Chi}^{2} .000$ \\
\hline \multicolumn{5}{|l|}{ Wave [reference: wave 1] } \\
\hline 2 & 1.097 & 1.168 & 1.007 & .969 \\
\hline 3 & 1.085 & 1.119 & .801 & 1.039 \\
\hline 4 & .950 & 1.131 & .742 & .976 \\
\hline 5 & .909 & 1.000 & $.688^{*}$ & .849 \\
\hline 6 & .911 & .944 & .948 & 1.065 \\
\hline 7 & .846 & 1.051 & 1.092 & 1.170 \\
\hline 8 & .985 & .915 & 1.179 & 1.126 \\
\hline 9 & .926 & 1.068 & .802 & 1.040 \\
\hline \multicolumn{5}{|c|}{ Relationship status [reference: not in a partnership, models $c$ and $d$ only] } \\
\hline In a romantic partnership & - & - & $4.107^{* * *}$ & $3.840 * * *$ \\
\hline
\end{tabular}

Obs $=$ number of observation periods; Resp = number of respondents; Trans = number of transitions in the sample; ${ }^{*} p<.05,{ }^{* *} p<.01,{ }^{* * *} p<.001$; Prob $>$ Chi2 $>.05$ in all tests of proportional hazards assumption based on Schoenfeld residuals. Models include controls for frailty (observations from the same individual).

Source: German Family Panel (pairfam) waves 1-10, own calculations. 


\section{Comparative Population Studies}

WWW.comparativepopulationstudies.de

ISSN: 1869-8980 (Print) - 1869-8999 (Internet)

\section{Published by}

Prof. Dr. Norbert F. Schneider

Federal Institute for Population Research D-65180 Wiesbaden / Germany

\section{(c) BY-SA}

2021

\section{Managing Editor}

Prof. Dr. Johannes Huinink

Dr. Katrin Schiefer

\section{Editorial Assistant}

Beatriz Feiler-Fuchs

Wiebke Hamann

\section{Layout}

Beatriz Feiler-Fuchs

E-mail:cpos@bib.bund.de

\section{Scientific Advisory Board}

Karsten Hank (Cologne)

Michaela Kreyenfeld (Berlin)

Marc Luy (Vienna)

Natalie Nitsche (Rostock)

Zsolt Spéder (Budapest)

Rainer Wehrhahn (Kiel)

\section{Board of Reviewers}

Bruno Arpino (Barcelona)

Kieron Barclay (Rostock)

Laura Bernardi (Lausanne)

Gabriele Doblhammer (Rostock)

Anette Eva Fasang (Berlin)

Michael Feldhaus (Oldenburg)

Tomas Frejka (Sanibel)

Alexia Fürnkranz-Prskawetz (Vienna)

Birgit Glorius (Chemnitz)

Fanny Janssen (Groningen)

Frank Kalter (Mannheim)

Stefanie Kley (Hamburg)

Bernhard Köppen (Koblenz)

Anne-Kristin Kuhnt (Duisburg)

Hill Kulu (St Andrews)

Nadja Milewski (Wiesbaden)

Roland Rau (Rostock)

Thorsten Schneider (Leipzig)

Tomas Sobotka (Vienna)

Jeroen J. A. Spijker (Barcelona)

Heike Trappe (Rostock)

Helga de Valk (The Hague)

Sergi Vidal (Barcelona)

Michael Wagner (Cologne) 